УДК 327-027.21/.22(560:5-15)

Дарія Ніколаєва,

аспірантка кафедри міжнародних відносин,

Одеський національний університет імені I. I. Мечникова

dasha_nik2008@ukr.net

https://orcid.org/0000-0002-7070-1334

https://doi.org/10.29038/2524-2679-2020-01-181-191

\title{
ІДЕОЛОГІЧНА ТА ГЕОПОЛІТИЧНА КОНКУРЕНЦІЯ ТУРЕЧЧИНИ Й ОАЕ: ТОЧКИ СПІВПРАЦІ ТА ЗІТКНЕННЯ
}

\begin{abstract}
Вивчено еволючію відносин Туреччини та ОАЕ на тлі комплексу проблем регіону Близького Сходу. Акцентовано на змінах зовнішньополітичного курсу Туреччини, починаючи від 2002 р. (прихід до влади Партії справедливості й розвитку): відродження ідеології пантюркізму (неопантюркізм), розповсюдження ідей неоосманізму, озвучення претензій на регіональне лідерство на Близькому Сході, претендування на роль посередника у вирішенні складних регіональних конфліктів i m. ін. Відзначено, що в ході цих прочесів близькосхідна політика Туреччини щораз частіме вступає в конфронтацію з інтересами як провідних акторів міжснародної політики, так і краӥн регіону. ОАЕ визначено серед тих держав, у відносинах із якими наявна висхідна динаміка розбіжностей та напруги. Відтак мета дослідження вивчення точок зіткнення інтересів Туреччини та ОАЕ, виявлення принципових відмінностей інтересів двох країн у регіоні Близького Сходу, а також наслідків зіткнень цих інтересів.

Аргументовано, щзо нинішні відносини Туреччини й ОАЕ характеризуються мінливим поєднанням доволі агресивної ідеологічної та геополітичної конкурениї̈, з одного боку, i ситуативної стратегічної співпраці - $з$ іншого. Підкреслено, щзо ОАЕ $е$ в групі опозииійно налаштованих до нинішнього зовнішньополітичного курсу Р. Т. Ердогана держав. Констатовано зниження від початку «Арабської весни» показників співпрачі Туреччини та ОАЕ за одночасного наростання міждержавної конфронтації. Це відбувається попри відсутність в ОАЕ, на відміну від багатьох держав Близького Сходу, османського минулого й трагічно забарвленої історичної пам'яті щодо турків. Відмінності між державами наявні в частині ставлення до руху «Братів-мусульман», військового перевороту 2013 р. у Єгипті, проблеми блокади Катару, створення буферної зони на північному сході Сирії, конкуренції інтересів у країнах Африканського Рогу, відносин зі сторонами громадянської війни в Лівії тощя. Аналіз специфіки відносин Туреччини з ОАЕ дає підставу припустити про відхід Туреччина від курсу на побудову політики «нуль проблем із сусідами», а відтак - посилення геополітичної ізолячії Туреччини.
\end{abstract}

Ключові слова: Туреччина, ОАЕ, Близький Схід, Партія справедливості та розвитку.

\section{1. ВСТУП}

Постановка проблеми та її значення. Близький Схід - поліконфліктогенний регіон: арабо-ізраїльський конфлікт, протистояння політичних сил сунітського та шиїтського спрямування, сирійський конфлікт тощо фокусують увагу на цьому регіоні. Водночас його значення зростає завдяки паливно-енергетичним

(С) Ніколаєва Д., 2020 
ресурсам. Після завершення активної фази «Арабської весни» країни Близького Сходу вступили у фазу «Арабської зими», яка розгорнулася після 2012 р. на тлі невдачі початкових прагнень учасників революцій в арабських країнах. У регіоні сформувалися коаліції, інтереси яких контрастують. Значною мірою відносини між державами на Близькому Сході визначає громадянська війна в Сирії, яка ведеться від 2011 р. Цей конфлікт вийшов за межі цієї держави та став точкою зіткнення інтересів регіональних і позарегіональних гравців. Відтак близькосхідна регіональна система міжнародних відносин зазнає турбулентної трансформації.

Після приходу у 2002 р. до влади в Туреччині Партії справедливості та розвитку, відбувся черговий розворот держави в східному напрямі. Результатом цього стала стрімка активізація міжнародних відносин Туреччини в регіоні Близького Сходу. Це супроводжується відродженням ідеології пантюркізму (неопантюркізм), розповсюдженням ідей неоосманізму. Задля просування власних зовнішньополітичних пріоритетів Туреччина використала переваги географічного розміщення, транзитного та економічного потенціалу, поєднання мусульманських традицій із європейськими стандартами й цінностями тощо [1, с. 87].

Туреччина намагається вийти на позиції провідного гравця міжнародної політики в регіоні Близького Сходу, демонструючи при цьому власну систему геополітичних інтересів (амбіції побудови «нової Османської імперії»). Вона претендує на роль посередника у вирішенні складних регіональних конфліктів. При цьому близькосхідна політика Туреччини часто не збігається з інтересами як провідних акторів міжнародної політики, так і власне країн регіону. Це призводить до посилення геополітичної ізоляції Туреччини. Однією з держав, під час співпраці з якою розбіжності та зіткнення наростають, власне, і є ОАЕ. Відносини Туреччини та OAE останніми роками характеризуються наростанням напруги, зміст якої потребує вивчення задля прогнозування змісту двосторонніх турецько-еміратських стосунків, а також подальшої ролі обох держав у політичній системі Близькосхідного регіону.

Аналіз останніх досліджень із цієї проблеми. Попри доволі значну увагу наукової спільноти до зовнішньої політики Туреччини, іiі відносини 3 OAE практично не вивчалися вітчизняною наукою. Із позицій політичної, економічної наук автори приділяють увагу насамперед зовнішньополітичному курсу Туреччини (А. Худолій) та ОАЕ (В. Назарков), питанням конфліктогенності міждержавних відносин у регіоні Близького Сходу (Л. Кияниця), безпековій політиці (Ю. Седляр), питанням економічної співпраці країн регіону (I. Колобердянко, І. Панасюк).

Формулювання мети статті. У статті поставлено мету - аналіз еволюції двосторонніх відносин Туреччини та ОАЕ, виявити принципові відмінності інтересів двох країн у Близькосхідному регіоні, а також наслідки зіткнень цих інтересів.

Методика дослідження. Регіональна взаємодія Туреччини з країнами Близького Сходу вивчається в рамках парадигми політичного реалізму, який 
розглядає підтримку рівноваги як спосіб збереження миру за максимально можливого задоволення інтересів кожної зі сторін. Метод кейс-стаді дає змогу проаналізувати 3 цих позицій різні сфери зовнішньополітичної активності Туреччини й OAE.

\section{2. РЕЗУЛЬТАТИ ДОСЛІДЖЕННЯ}

Нинішні відносини Туреччини та ОАЕ характеризуються мінливим поєднанням доволі агресивної ідеологічної й геополітичної конкуренції, 3 одного боку, і ситуативної стратегічної співпраці - з іншого. ОАЕ є однією 3 тих держав, які перебувають в опозиції до нинішнього зовнішньополітичного курсу Р. Т. Ердогана щодо держав Близького Сходу та Північної Африки. Відносини двох держав, попри короткий час співпраці, еволюціонували від налагодження міцних контактів до поступового звуження співпраці за нарощення конфронтації.

До 2010-х рр. Туреччина та ОАЕ підтримували міцні звесязки, зокрема ОАЕ входили до числа провідних торговельних партнерів Туреччини в арабському світі, були серед основних інвесторів. Такі відносини вдалося налагодити, адже OAE не мали османського минулого, на відміну від багатьох арабських держав; відтак відсутня трагічно забарвлена історична памеять щодо турків. Висхідна дипломатична активність Туреччини на Близькому Сході у 2000-pp. також ще не турбувала ОАЕ, на відміну від Саудівської Аравії або ж Єгипту.

Утім, ще до початку «Арабської весни» намітилися перші провісники майбутньої ескалації напруги у двосторонніх турецько-еміратських відносинах. Мова, передусім, про відмінне ставлення двох держав до руху «Братівмусульман». У рамках своєї ширшої зовнішньополітичної мети - здійснювати керівну роль у мусульманському світі - Туреччина зміцнювала зв"язки 3 «Братами-мусульманами» та іншими релігійними рухами, які неоднозначно оцінюються акторами міжнародної політики. Ще у 2000 рр. Туреччина стала центром зустрічей ісламістських діячів й обговорення загальних проблем ними (спільноти усіх мусульман як релігійної громади). Керівна в Туреччині Партія справедливості та розвитку сприяла й нині сприяє реалізації цієї політики.

Натомість ОАЕ розпочала «культурну війну» проти «Братів-мусульман», витісняючи або маргіналізуючи членів і симпатиків руху в державних установах, навчальних закладах. Якщо у 2000-х рр. це була ще повільна, неінтенсивна «культурна війна», переважно прихована від громадськості, то після початку «Арабської весни» вона інтенсифікувалася. Тоді «Братимусульмани» були запідозрені в змові проти політичного режиму ОАЕ. У грудні 2011 р. шість членів руху позбавлено громадянства, а в березні 2012 p. пройшла хвиля їх арештів. Риторика керівного режиму ОАЕ полягала в позиціюванні «Братів-мусульман» як загрози безпеці країнам регіону Перської затоки.

Саме «Арабська весна» загострила низку питань, які відрізняли Туреччину та ОАЕ, але не були досі актуалізовані. Якщо Туреччина сприйняла «Арабську 
весну», то ОАЕ перебували на позиції, що ці революції посилять вплив «Братівмусульман», а відтак чинні режими Близькосхідного регіону, яких досі не охопила «Арабська весна», можуть бути повалені. Відтак у листопаді 2014 р. в OAE рух «Братів-мусульман», його місцеві філії, а також організації «АльІсла», «Фронт ан-Нусра» та ін. визнано терористичними структурами.

Відмінності в політичних позиціях Туреччини та OAE посилились у зв"язку з військовим переворотом у липні 2013 р. в Сгипті та відстороненням від влади тодішнього глави держави М. Мурсі. Туреччина жорстко відреагувала на ці події та подальше придушення «Братів-мусульман» у Єгипті. Туреччина та Єгипет тоді відкликали послів і підтримують стосунки на найнижчому щаблі дипломатичних контактів - рівні повірених у справах. ОАЕ, навпаки, підтримали новий режим єгипетського президента А. I. ac-Сici, надавши щедру дипломатичну та фінансову підтримку й сприяючи його консолідації; ця підтримка зберігається й нині.

В останні роки з боку Туреччини новими діями-подразниками щодо ОАЕ стали надання притулку на своїй державній території членам руху «Братівмусульман», переслідуваних у Сгипті; підтримка Туреччиною Катару в умовах його блокади низкою держав Близького Сходу та розміщення в цій державі двох турецьких військових баз; військові операції на північному сході Сирії, підконтрольній курдам; розміщення турецьких військ у Лівії, де триває громадянська війна; розвідка нафто-газових родовищ на континентальному шельфі Республіки Кіпр. Також існує й низка інших значущих чинників, які зумовили звинувачення владою ОАЕ Туреччини в «колоніальних ілюзіях» та поширення оцінок, що Туреччина відійшла від узятого курсу на побудову політики «нуль проблем зі сусідами» до політики «проблем з усіма».

Водночас із боку ОАЕ таким новим подразником, насамперед, виступила солідаризація із Саудівською Аравією в розвитку нею звеязків із Загонами народної самооборони, які Туреччина позиціює як сирійську філію забороненої Робітничої партії Курдистану. Зокрема, турецька сторона оцінює розмір наданої ОАЕ та Саудівською Аравією такої допомоги в 1 млрд дол. США [7]. Чинник тиску ОАЕ на Катар також сприяв ескалації напруги в турецько-еміратських двосторонніх взаєминах.

OAЕ різко критикують план Туреччини створити буферну зону на північному сході Сирії. Ці дії еміратська сторона характеризує як наміри Туреччини географічно ізолювати сирійських курдів [4]. ОАЕ вважають неприйнятною таку присутність неарабських а́кторів в арабській країні, якою $\epsilon$ Сирія. ОАЕ декларує всебічну прихильність до сирійських курдів і намір їх захисту. Натомість Туреччина розглядає бездержавних курдів як повстанцівтерористів [8]. Солідаризація ОАЕ з курдськими націоналістичними силами в Сирії відбиває намір ОАЕ стримувати турецький вплив у цій країні та позиціювати себе як впливового а́ктора процесу вирішення громадянського конфлікту в Сирії, посередника, фасиліатора діалогу між сторонами конфлікту.

Критичне ставлення ОАЕ до воєнної кампанії Туреччини на північному сході Сирії є результатом більш масштабного суперництва Абу-Дабі та Анкари, 
яке викликане зближенням Туреччини з Катаром, тісними звеязками Анкари 3 «Братами-мусульманами» й конкурентними інтересами в країнах Африканського Рогу. Напруженість щодо цих питань незмінно посилюється після того, як президент Туреччини Р. Т. Ердоган звинуватив ОАЕ в підтримці перевороту 2016 р. проти його уряду, однак сирійське питання до 2018 р. залишалося вторинною точкою протистояння між ОАЕ та Туреччиною.

Після того, як Туреччина здійснила на початку 2018 р. інтервенцію в місто Афрін (операція «Оливкова гілка»), спрямовану проти курдських Загонів народної самооборони (YPG), у міжнародному політичному дискурсі почали говорити про «чинник Афрін» в еволюції турецько-еміратських відносин. ОАЕ сприйняли операцію «Оливкова гілка» як таку, що не лише загрожує Сирії, а й загалом арабському світу. Зовнішньополітичне відомство ОАЕ відреагувало на втручання Туреччини в курський анклав Афрін озвученням потреби арабським державам невідкладно починати «будувати та відновлювати концепцію національної безпеки арабських країн на реалістичній і сучасній основі; без цього араби будуть маргіналізовані» [3]. Підставою цього була інформація про розграбування та інші злочини Туреччини в курдському анклаві. Відтак для OAE «чинник Афрін» став передовим у боротьбі проти турецького експансіонізму стосовно арабського світу. Загалом ОАЕ, на відміну від Туреччини, перебувають на позиції, що неможливо досягти стабільності в Сирії за допомогою військового втручання.

ОАЕ спільно з іншими арабськими державами активізували перемовини 3 різними а́кторами сирійської політики (Демократична партія Курдистану, Робітнича партія Курдистану та ін.), готували курдське ополчення до ймовірної подальшої інтервенції Туреччини тощо. До серпня 2018 р. ОАЕ інвестували 50 млн дол. США у райони північно-східної Сирії, звільнені від контролю Ісламської Держави. Ці вкладення капіталу поєднувалися зі 100 млн дол. США інвестицій Саудівської Аравії в райони Сирії, контрольовані курдськими бійцями Сирійських демократичних сил (SDF). Такі дії призвели до озвучення в турецькому провладному політичному дискурсі думок про неминучу перспективу арабо-турецького конфлікту в Сирії та звинувачень ОАЕ в спонсорстві тероризму на північному сході Сирії.

У ході державного візиту в березні 2018 р. глави ОАЕ Халіфа бін Заїд Аль Нахайяна до Єгипту ним у розмові 3 президентом Єгипту А. Ф. Ас-Сісі Туреччину (а також Іран та Ізраїль) віднесено до держав, які найбільше підривають інтереси арабських держав [12]. Аналогічна риторика озвучується й Саудівською Аравією («трикутник зла» в складі Туреччини, Іран і радикальних ісламістських груп). Зі свого боку, Туреччина звинувачує ОАЕ в підтримці курдського тероризму на півночі Сирії, спонсорстві сил, проти яких спрямована військова кампанія Туреччини на півночі Сирії.

Останнім часом Туреччина почала вдаватися до нових тактик у відносинах 3 ОАЕ. Зокрема, у 2018 р. в Анкарі перейменували 613-у вулицю, на якій розміщена дипломатична установа OAE, на честь османського генерала початку XX ст. Фахреддіна-паші. Це сталося після резонансного посту у Twitter очільника МЗС ОАЕ А. М. Гаргаша, у якому містилася негативна оцінка 
Фахреддіна-паші [10]. Відомо, що цей османський генерал очолював останній гарнізон, який склав зброю перед військами Антанти, у ході чого Медіна у 1916 р. була здана британським військам. Еміратський високопосадовець озвучує оцінки, що Фахреддін-паша здійснював злочини проти населення, викрав із Медини ісламські реліквії, перевізши їх до Стамбула. Туреччина оцінює згадану та інші публічні заяви державного міністра закордонних справ OAE A. М. Гаргаша як розгортання загрозливої антитурецької кампанії за

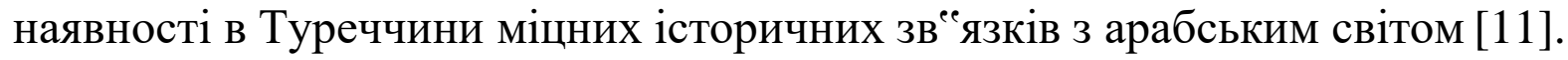

Ще одним прикладом таких новітніх тактик слугує кейс внесення в грудні 2019 р. турецьким урядом палестинського політика М. Дахлана, який нині проживає в ОАЕ, до «червоного списку» терористів, розшукуваних Туреччиною. Його Туреччина звинувачує в причетності до спроби державного перевороту 2016 р. проти Р. Т. Ердогана та причетності до вбивства журналіста Дж. Хашкаджі. ОАЕ, які надали притулок М. Дахлану, звинувачуються в «переховуванні терориста». 700 тис. дол. США обіцяно турецькою стороною за інформацію щодо місцеперебування М. Дахлана. Туреччина має підозру, що М. Дахлан має стосунок до функціонування шпигунської мережі OAE на турецькій території. Імовірно, Туреччина хоче використати звинувачення проти цього діяча в рамках загальної конкуренції з ОАЕ та Саудівською Аравією за регіональний вплив.

Зауважимо, що Туреччина загалом увиразнює настрої підозри ОАЕ в шпигунстві, періодично затримує громадян ОАЕ за такими звинуваченнями. Навіть більше: Туреччина озвучує звинувачення в причетності ОАЕ до спроби державного перевороту 2016 р. Очільник МЗС Туреччини М. Кавусоглу у зверненні до ОАЕ констатував: «Ми знаємо, що ваша країна виділила 3 млрд дол. США фінансової підтримки на спробу перевороту в Туреччині» [6, с. 188-189]. Висловлювалися припущення, що ці кошти були вкладені в антитурецьку пропаганду, нецивілізований лобізм, оплату послуг онлайнтролів, розвідку тощо.

Провладні турецькі медіа (наприклад консервативна газета Yeni Şafak та iн.) увиразнюють доволі агресивний щодо ОАЕ та його державних високопосадовців дискурс. Наприклад, шейха М. бен Заїд Аль Нахайяна, спадкового принца емірату Абу-Дабі, названо «підлим», таким, що використовує всеможливі заходи для підриву спроб Туреччини розвивати дружні звеязки 3 арабськими країнами й саботажу зусиль Анкари щодо розробки спільних ініціатив щодо вирішення криз [2]. Турецькі медіа вдаються до образних образливих порівнянь ОАЕ 3 раковою клітиною, яка пустила метастази в Єгипті, Лівії й інших країнах [2]. Складається враження, що Туреччина позиціює ОАЕ як ініціатора різноманітних антитурецьких провокацій.

Відзначимо активну підтримку ОАЕ (спільно із Саудівською Аравією) Греції та Республіки Кіпр у протидії діям Туреччини в Східному

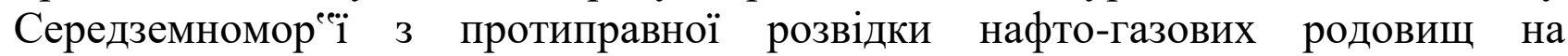
континентальному шельфі. Також OAE (як і Саудівська Аравія, Бахрейн, Сгипет) різко протестують проти турецької інтервенції в Лівію, розпочатої на 
початку 2020 р. Щодо лівійського конфлікту, то Туреччина звинувачує ОАЕ в постачанні зброї опозиційній стороні конфлікту, очолюваній генералом Х. Хафтаром.

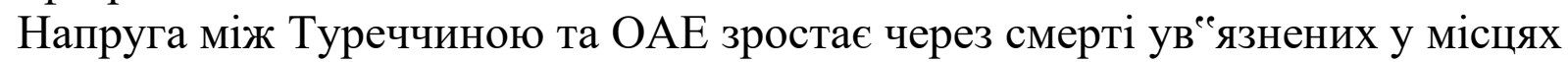
позбавлення волі Туреччини. Наприклад, у квітні 2019 р. за незеяясованих обставин помер палестинець 3. Ю. Мубарак Хасан, звинувачений у шпигунстві на території Туреччини на користь ОАЕ. Офіційною версією Туреччини $\epsilon$ самогубство, а не вбивство (повішання). Водночас родина померлого відкидає цю версію, вимагаючи об єективного розслідування.

Про зростання рівня напруги між Туреччиною та ОАЕ свідчить також те, що Р. Т. Ердоган під час свого офіційного візиту в липні 2017 р. (після початку Катарської кризи) до країн Перської затоки відвідав Саудівську Аравію та інші країни регіону, але не здійснив офіційного візиту до ОАЕ.

Особливої уваги в нашому аналізі заслуговують турецько-еміратські економічні відносини й динаміка їх інтенсивності. Ситуація щодо економічної співпраці між країнами Близького Сходу демонструє, що політики цього регіону активно використовують економічні важелі для винагороди або ж покарання інших держав за політичними причинами. Мова про зміни в обсягах двосторонньої торгівлі, інвестування, купівлі нерухомості на території Туреччини, туризм. Згадані чинники традиційно використовуються на Близькому Сході як інструменти дипломатичного впливу.

В останні десятиліття Туреччина інтенсивно розширяла економічні відносини з нафтовими арабськими державами. ОАЕ та Саудівська Аравія були пріоритетними економічними партнерами Туреччини в регіоні Близького Сходу. Від цієї співпраці Туреччина отримала значну вигоду, оскільки активізувалися торгівля, туризм та інвестиційна діяльність. Однак проаналізоване вище погіршення політичних відносин між державами поставило під сумнів подальшу перспективу масштабної економічної співпраці. Наведені нижче дані про експорт та імпорт Туреччини в період 2002-2018 pp.

демонструють зміни в торговельному партнерстві цієї держави з країнами

Близького Сходу: воно скорочується щодо ОАЕ (як і Саудівської Аравії),

розширюючись з Катаром (від початку його блокади у 2017 р.). Спад у

торговельно-інвестиційних відносинах між Туреччиною й ОАЕ певною мірою компенсується активізацією відносин із Катаром.

Таблиия 1

Експорт Туреччини (млн дол. США)

\begin{tabular}{|l|c|c|c|c|c|c|}
\hline Держава/ рік & $\mathbf{2 0 0 2}$ & $\mathbf{2 0 1 0}$ & $\mathbf{2 0 1 5}$ & $\mathbf{2 0 1 6}$ & $\mathbf{2 0 1 7}$ & $\mathbf{2 0 1 8}$ \\
\hline ОАЕ & 452 & 3,333 & 4,681 & 5,407 & 9,184 & 3,138 \\
\hline $\begin{array}{l}\text { Саудівська } \\
\text { Аравія }\end{array}$ & 547 & 2,218 & 3,473 & 3,172 & 2,735 & 2,636 \\
\hline Катар & 15 & 163 & 423 & 439 & 649 & 1,097 \\
\hline
\end{tabular}

\footnotetext{
${ }^{1}$ Дані про експорт та імпорт укладено на основі даних UN Comtrade Database (https://comtrade.un.org/)
} 
Таблиия 2

Імпорт Туреччини (млн дол. США)

\begin{tabular}{|l|c|c|c|c|c|c|}
\hline Держава/ рік & $\mathbf{2 0 0 2}$ & $\mathbf{2 0 1 0}$ & $\mathbf{2 0 1 5}$ & $\mathbf{2 0 1 6}$ & $\mathbf{2 0 1 7}$ & $\mathbf{2 0 1 8}$ \\
\hline ОАЕ & 100 & 698 & 2,009 & 3,701 & 5,547 & 3,781 \\
\hline $\begin{array}{l}\text { Саудівська } \\
\text { Аравія }\end{array}$ & 778 & 1,381 & 2,117 & 1,835 & 2,110 & 2,318 \\
\hline Катар & 11 & 177 & 361 & 271 & 264 & 335 \\
\hline
\end{tabular}

Торгівля Туреччини з ОАЕ різко знизилася після початку Катарської кризи у 2017 р.: експорт зменшився на 66 \%, імпорт - на 32 \%. Ці падіння були відчутні для Туреччини, оскільки ОАЕ були на той час її найбільшим торговим партнером. Водночас зменшення торгівлі Туреччини із Саудівською Аравією не зазнало таких самих різких змін, хоча і Саудівська Аравія, і ОАЕ мають єдину, протилежну до турецької, позицію щодо Катару та інших гострих проблем зовнішньої політики.

Щодо іноземних інвестицій, то останнім часом ОАЕ підтримує відкриті умови для залучення іноземного капіталу, а Туреччина створила привабливі умови інвестування. Великі масштаби будівництва, масштабні інфраструктурні проєкти довготривало уможливлювали взаємовигідні інвестиційні можливості для інвесторів в обох країнах. Завдяки великим доходам від експорту паливноенергетичних ресурсів ОАЕ стали головними постачальниками фінансового капіталу та прямих іноземних інвестицій в економіку Туреччини після 2002 p. (прихід до влади в Туреччині Партії справедливості та розвитку, політика якої певний час спрямовувалася на активізацію співпраці з арабськими державами). Однак Катарська криза зумовила зменшення інвестицій в економіку Туреччини з боку країн, налаштованих опозиційно до Катару. Із наведених нижче даних видно зменшення інвестицій ОАЕ в економіку Туреччини.

Таблиия 3

Прямі іноземні інвестиції в Туреччину (млн дол. США)

\begin{tabular}{|l|l|l|l|l|l|l|l|l|l|}
\hline $\begin{array}{l}\text { Держава/ } \\
\text { роки }\end{array}$ & $\mathbf{2 0 0 0}$ & $\mathbf{2 0 0 3}$ & $\mathbf{2 0 0 7}$ & $\mathbf{2 0 1 1}$ & $\mathbf{2 0 1 4}$ & $\mathbf{2 0 1 5}$ & $\mathbf{2 0 1 6}$ & $\mathbf{2 0 1 7}$ & $\mathbf{2 0 1 8}$ \\
\hline OAE & 1 & 4 & 6,289 & 7,233 & 6,847 & $\begin{array}{l}4,573 \\
-33 \%\end{array}$ & $\begin{array}{l}3,585 \\
-22 \%\end{array}$ & $\begin{array}{l}4,079 \\
+14 \%\end{array}$ & $\begin{array}{l}2,997 \\
-27 \%\end{array}$ \\
\hline
\end{tabular}

Водночас не лише солідаризація Туреччини 3 Катаром вплинула на скорочення інвестицій з ОАЕ. Інші держави переважно так само відреагували на запроваджені у 2018 р. санкції США щодо турецьких високопосадовців, обвал турецької ліри, входження країни в рецесію тощо.

Щодо інвестування в турецьку житлову та комерційну нерухомість, то інтерес до неї в громадян арабських держав різко зріс після внесення змін до законодавства, завдяки яким посилився інтерес до набуття права власності на неї. Основна мотивація набуття нерухомості в Туреччині (найперше - на

\footnotetext{
${ }^{1}$ За даними Central Bank of Turkey, Statistics Department.
} 
курортному узбережжі) громадянами ОАЕ та інших країн Перської затоки можливість використовувати його для відпочинку в спекотні місяці. Однак від 2018 р. відбувається спад обсягів продажу турецької нерухомості [5, с. 5-6], причиною чого $\epsilon$ поширювані політиками OAE настрої застереження від доцільності купівлі нерухомості саме в Туреччині. Також відзначимо й тенденцію до зниження кількості туристів з ОАЕ до Туреччини.

\section{3. ВИСНОВКИ ТА ПЕРСПЕКТИВИ ПОДАЛЬШИХ ДОСЛІДЖЕНЬ}

Очевидно, що для відновлення балансу у відносинах ОАЕ з Туреччиною потрібно, щоб Туреччина невідступно поважала суверенітет арабських суверенних акторів [9]. Очевидно, що присутність Туреччини та OAE у регіонах Близького Сходу, Північної та Східної Африки зорієнтована більше на довгострокову геостратегічну перспективу, аніж на короткострокові військові діï. 3 огляду на активність Туреччини та OAE у розвитку економічних $\mathrm{i}$ військових відносин у названих регіонах, імовірно, їх суперництво лише посилюватиметься в найближчі роки.

\section{СПИСОК ВИКОРИСТАНИХ ДЖЕРЕЛ}

1. Стародуб, Т., Сапицька, І. (2009). Нові підходи до формування системи регіональної безпеки у Чорноморсько-Каспійському регіоні. Стратегічна панорама, № 2, С. 86-95.

2. Acet, M. (1 Feb 2020). Turkey started to respond to UAE in the only language it understands. Yeni Şafak.

3. Afrin highlights need to rebuild Arab national security, says Gargash (2018). URL: https://www.arabnews.com/node/1230456/middle-east

4. Gargash: We reject establishment of buffer zone in Syria (2020). URL: https://www.middleeastmonitor.com/20190201-gargash-we-reject-establishment-of-buffer-zone-insyria/

5. Habibi, N. (2019). Turkey"es Economic Relations with Gulf States in the Shadow of the 2017 Qatar Crisis. Middle East Brief, № 132.

6. Karakus, M. (2019). Interpreting the July 15 failed coup attempt in Turkey according to the Barakah Circle Theory of Bayt al-Maqdis. Journal of Islamicjerusalem Studies, № 19 (2), P. 181-194.

7. Merkezi, H. (2019). PKK'ya 1 milyar dolar. URL: https://www.yenisafak.com/dunya/ pkkya-1-milyar-dolar-3466237

8. Schmitt, E., Haberman, M., Wong, E. (Oct 7, 2019). President Endorses Turkish Military Operation in Syria, Shifting U.S. Policy. The New York Times.

9. Senior UAE official says Turkey-Arab relations 'not in best state' (2018). URL: https://ca.reuters.com/article/topNews/idCAKCN1GM0DM-OCATP

10. Turkey, UAE in row over Ottoman pasha (20 Dec 2017). Hürriyet Daily News.

11. UAE foreign minister's Afrin remarks 'not' an indication of goodwill, Turkey says (2018). URL: https://www.dailysabah.com/diplomacy/2018/03/20/uae-foreign-ministers-afrin-remarks-notan-indication-of-goodwill-turkey-says

12. Wirtschafter, J. (2018). Sheikh Abdullah says Turkey among the nations posing a threat to Arab states. URL: https://www.thenational.ae/world/mena/sheikh-abdullah-says-turkey-amongthe-nations-posing-a-threat-to-arab-states-1.714233 


\section{IDEOLOGICAL AND GEOPOLITICAL COMPETITION BETWEEN TURKEY AND THE UAE: POINTS OF COOPERTION AND CONFRONTATION}

The evolution of Turkey-UAE relations is studied against the background of a set of problems that characterize the Middle East region. Emphasized on changes in Turkey's foreign policy since 2002 (coming to power of the Justice and Development Party): revival of the ideology of Pan-Turkism (Neo Pan-Turkism), dissemination of neo-Ottomanism ideas, voicing of claims for regional leadership in the Middle East, etc. It is noted that in the course of these processes, Turkey's Middle East policy is increasingly confronted with the interests of both leading international and political actors. Ain region. The UAE has been identified among those countries with which there is increasing dynamics of differences and tensions. The purpose of the study is therefore to examine the points of conflict of interest of Turkey and the UAE, to identify the fundamental differences between the interests of the two countries in the Middle East region, as well as the consequences of conflicts of interests.

It is argued that the current relations between Turkey and the UAE are characterized by a changing combination of rather aggressive ideological and geopolitical competition, on the one hand, and situational strategic cooperation, on the other. It is emphasized that the UAE is in the group of opposing states of the current foreign policy of RT Erdoğan. There has been a decrease since the beginning of the Arab Spring on the cooperation between Turkey and the UAE, with the simultaneous increase of inter-state confrontation. This is despite the absence in the UAE, in contrast to many Middle Eastern states, the Ottoman past and tragically coloured historical memory of the Turks. Differences between states are related to the Muslim Brotherhood movement, the 2013 military coup in Egypt, the blockade of Qatar, the creation of a buffer zone in northeastern Syria, competing interests in the Horn of Africa, relations with the parties to the civil war in Libya, etc. Analysing the specifics of Turkey's relations with the UAE suggest that Turkey's departure from the course is building a «Zero Problems with our Neighbors» policy and, consequently, enhancing Turkey's geopolitical isolation.

Key words: Turkey, UAE, Middle East, Justice and Development Party.

\section{REFERENCES}

1. Starodub, T., Sapytska, I. (2009). Novi pidkhody do formuvannia systemy rehionalnoi bezpeky u Chornomorsko-Kaspiiskomu rehioni. Stratehichna panorama, № 2, S. 86-95.

2. Acet, M. (1 Feb 2020). Turkey started to respond to UAE in the only language it understands. Yeni Şafak (in English).

3. Afrin highlights need to rebuild Arab national security, says Gargash (2018). URL: https://www.arabnews.com/node/1230456/middle-east (in English).

4. Gargash: We reject establishment of buffer zone in Syria (2020). URL: https://www.middleeastmonitor.com/20190201-gargash-we-reject-establishment-of-buffer-zone-insyria/ (in English).

5. Habibi, N. (2019). Turkeyees Economic Relations with Gulf States in the Shadow of the 2017 Qatar Crisis. Middle East Brief, № 132 (in English).

6. Karakus, M. (2019). Interpreting the July 15 failed coup attempt in Turkey according to the Barakah Circle Theory of Bayt al-Maqdis. Journal of Islamicjerusalem Studies, № 19 (2), P. 181-194 (in English).

7. Merkezi, H. (2019). PKK'ya 1 milyar dolar. URL: https://www.yenisafak.com/dunya/ pkkya-1-milyar-dolar-3466237 (in English).

8. Schmitt, E., Haberman, M., Wong, E. (Oct 7, 2019). President Endorses Turkish Military Operation in Syria, Shifting U.S. Policy. The New York Times (in English).

9. Senior UAE official says Turkey-Arab relations 'not in best state' (2018). URL:

https://ca.reuters.com/article/topNews/idCAKCN1GM0DM-OCATP (in English).

10. Turkey, UAE in row over Ottoman pasha (20 Dec 2017). Hürriyet Daily News (in English). 
11. UAE foreign minister's Afrin remarks 'not' an indication of goodwill, Turkey says (2018). URL: https://www.dailysabah.com/diplomacy/2018/03/20/uae-foreign-ministers-afrin-remarks-notan-indication-of-goodwill-turkey-says (in English).

12. Wirtschafter, J. (2018). Sheikh Abdullah says Turkey among the nations posing a threat to Arab states. URL: https://www.thenational.ae/world/mena/sheikh-abdullah-says-turkey-amongthe-nations-posing-a-threat-to-arab-states-1.714233 (in English).

Матеріал надійшов до редакції 07.02.2020 p.

\section{УДК 327 (73)}

\section{Валерій Мирончук,}

студент магістеріуму спеціальності «Міжнародні відносини, суспільні

комунікації та регіональні студії»,

Національний університет «Острозька академія»,

35800, Україна, Рівненська обл., м. Острог, вул. Семінарська, 2

valerii.myronchuk@oa.edu.ua

\section{Тетяна Сидорук,}

доктор політичних наук, професор,

завідувач кафедри міжнародних відносин, Національний університет «Острозька академія», 35800, Україна, Рівненська обл., м. Острог, вул. Семінарська, 2 tetiana.sydoruk@oa.edu.ua

https://orcid.org/0000-0002-7231-9884

\section{Ірина Тимейчук,}

кандидат філологічних наук, доцент кафедри міжнародних відносин, Національний університет «Острозька академія», 35800, Україна, Рівненська обл., м. Острог, вул. Семінарська, 2 iryna.tymeychuk@oa.edu.ua https://orcid.org/0000-0003-3640-9847 https://doi.org/10.29038/2524-2679-2020-01-191-201

\section{ТЕНДЕНЦІЇ ЗОВНІШНЬОПОЛІТИЧНОГО КУРСУ США ЗА АДМІНІСТРАЦІї ДОНАЛЬДА ТРАМПА}

У статті проаналізовано нові тенденції в зовнішній політищі США після приходу в Білий дім Дональда Трампа, а також їх вплив на розвиток сучасної системи міжнародних відносин. Співпрачя Украӥни зі США $є$ ключовим пріоритетом у реалізачії національних інтересів нашої держави, тому розуміння нинішніх підходів США до міжнародних відносин є принџипово важливим із погляду продовження плідної співпраці з ними. На основі аналізу Стратегії національної безпеки США 2017 р. та інших документів автори доводять, щуо зовнішня політика США набуває рис

(C) Мирончук В., Сидорук Т., Тимейчук I., 2020 